GEOGRAFIE • ROK 2015 • ČÍSLO 3 • ROČNÍK 120

ERNŐ MOLNÁR, GÁBOR KOZMA, JÁNOS PÉNZES

\title{
INTRA-REGIONAL TRADE IN THE AUTOMOTIVE INDUSTRY OF EAST-CENTRAL EUROPE
}

\begin{abstract}
MOLNÁR, E., KOZMA, G., PÉNZES, J. (2015): The intra-regional trade relations in the automotive industry of East-Central Europe. Geografie, 120, No. 3, pp. 297-313. The paper examines the intra-regional trade of the automotive industry in East-Central Europe as the prioritized target of foreign direct investment and a production site of growing importance in the sector. Our main assumption is that cross-border agglomeration tendencies (reflected in intra-regional trade relations), with the upgrading of the region, play an increasingly important role. After a review of the relevant literature, the paper analyses and explains how the significance and the structure of the connections within the region have recently changed. The empirical survey focuses on the first decade of the $21^{\text {st }}$ century, with the East-Central European countries (Czechia, Hungary, Poland, Romania, Slovakia and Slovenia) characterized by the considerable presence of the automotive industry.

KEY WORDS: automotive industry - division of labour - East-Central Europe - value chains.
\end{abstract}

This paper was supported by the János Bolyai Research Scholarship of the Hungarian Academy of Sciences.

\section{Introduction: question, data and methods}

The automotive industry is a strongly internationalized industry of significant global size, for which East-Central Europe has become an increasingly important location since the political transformation in the early 1990s. Its relevance in the field of economic policy is inherent with its dynamics and also with its multiplier effects. The automotive industry relies on an extensive network of suppliers, which contributes not only to a quantitative increase of local value added and employment growth, but also - by way of the quality expectations toward the suppliers - to the strengthening of the competitiveness of small and medium size enterprises. Due to its modernization effect, it is considered as a strategic industry around the world. On the other hand, some serious doubts have also been raised, due to the organizational structure of the automotive industry, regarding the positive effects it has on the local economic players (Humphrey, Memedovic 2003; Kemenczei, Nikodémus 2006; Rugraff 2010; van Biesebroeck, Sturgeon 2010; Dicken 2011).

The interest of authors researching the automotive industry and its development in East-Central Europe is mainly focused on the FDI-led organizational and spatial transformation after the change of regime, the impact of the global economic crisis, as well as the structural changes (upgrading) within the sector. Some of these studies contain comparative analyses of countries or value 
chains of several car producers, emphasizing the similarities and differences in their development. At the same time, less attention has been devoted to the relations across the borders of the national economies. It is, however, a relevant research subject emerging from the organizational and spatial characteristics of the sector. Addressing this problem is useful for a better understanding of the geography of the automotive industry, contributing to a more nuanced appreciation of the regional competition surrounding the choice of the locations for the plants, as well as the regional embeddedness affecting the local future of the branch. After summarizing the relevant findings in the literature, our study focuses on the intra-regional trade relations within the automotive industry. With the upgrading of the region as a location of the sector, we assume (1) first, the intensification of the intra-regional trade, and (2) second, a selective development resulting in different trade volumes and growing importance of intermediate products in the automotive industry of the East-Central European countries.

The analysis covered six East-Central European countries, each having actually, as a result of development tendencies of the last two decades, a significant export surplus in the automotive industry. Our study is based on the database of the International Trade Centre: we relied on import and export data pertaining to motor vehicles and vehicle parts, as well as internal-combustion engines and their components. The explanations are based - besides the relevant literature - on data of international sectoral organizations (ACEA, OICA), on press releases as well as on primary research by Hungarian sectoral organizations (MAGE - Association of the Hungarian Automotive Industry, MAJOSZ - Association of Hungarian Automotive Component Manufacturers) and Hungarian industrial parks with automotive enterprises.

\section{East-Central Europe in the global automotive industry}

Research papers describe the automotive industry as a global industry operating in the framework of regional production systems, characterized by the dominant role of a relatively small number of large, strongly internationalized corporations concentrating much economic power, as well as local manufacturing of parts and assembly of motor vehicles on the most important markets. This duality may be traced back, on the one hand, to the high barriers to entry and concentration processes due to the competition in the sector, which are typical of capital-intensive industries, and on the other hand, to political pressures and tendencies of de-concentration due to technical reasons. In the interest of providing access to the local markets, it is "expected" that the foreign car manufacturers establish local plants, while the local assembly of automobiles requires a certain percentage of local value added and, due to the need to ensure flexible operations, the geographical proximity of key suppliers (Humphrey, Memedovic 2003; van Biesebroeck, Sturgeon 2010; Dicken 2011).

As a consequence of lean production methods, the largest part of the valuecreation activity of value chains is shifted to a network of suppliers that are different in terms of the complexity of the activities and the method of coordination used. Car manufacturers keep the design and assembly of the 
vehicles, as well as the manufacturing of the main components, within their own organizational structures, while maintaining very close relationships with the first-tier suppliers responsible for the development and manufacturing of complete subsystems, which also have an impact on the choice of plant location and play an increasing role in organizing the supplier pyramids. In contrast with the global companies situated on the top of these structures, producing significant value added and showing strong organizational concentration, on the lower levels we encounter local players manufacturing simpler parts, which are less profitable enterprises and have more unstable business relationships (Humphrey, Memedovic 2003; Gereffi, Humphrey, Sturgeon 2005; Sturgeon, van Biesebroeck, Gereffi 2008).

The sector shows shifts in its spatial structure: markets of large growth potential, as well as peripheries of regional economic integrations have increasing significance, as plant locations (Sturgeon, van Biesebroeck, Gereffi 2008; Wójtowicz, Rachwal 2014). East-Central Europe belongs in the latter of these two categories. In the dynamics of its automotive industry, a significant role is played by its location within the European Union (geographical and cultural proximity of Western Europe, political stability), the relatively cheap and welltrained workforce, available in a flexible way, which allows more cost-efficient production, as well as the local strategies of economic development relying on foreign direct investments, manifesting itself in investment incentives and infrastructural developments. For investors of the sector, initially arriving with strategies targeted at promising new markets, it was increasingly the seeking for higher efficiency of an export-oriented production that was the most important motivation (Pavlínek 2002; Radosevic, Rozeik 2005; Havas 2007; Kiss 2007; Szalavetz 2011).

East-Central Europe is referred to as a location for automotive plants characterized by lower value added and higher labour intensity, where mass production of small passenger cars and low volumes of niche automobiles are present as well as labour-intensive parts are manufactured (Pavlínek 2002; Schamp 2005; Jürgens, Krzywdzinski 2009; Klauber et al. 2011). However, the examination of upgrading processes, interpreted as the only way for durable development because of the expected and experienced eastward relocation of some activities based on cheap labour, is gaining importance (Jürgens, Krzywdzinski 2011; Barta 2012). The papers dealing with the structural changes of the automotive industry, as the most general phenomenon, describe the increase in efficiency, based on advanced technologies and new forms of work organization (Akbar, Ferenčíková 2007; Pavlínek, Ženka 2011; Hagiu, Platis 2012). More and more elements of the automotive value chains settle in the region, which can be identified in the increasing complexity of the production activities, in the development of the suppliers' background and the appearance of functions other than production. Also the spatial relationships of the region's automotive industry are increasingly diversified (Winter 2006; Jürgens, Krzywdzinski 2009; Molnár 2009; Pavlínek, Domanski, Guzik 2009).

On the other hand, upgrading is dependent on the strategies of multinational companies (Fuchs, Winter 2008; Pavlínek, Domanski, Guzik 2009) situated in top positions of the supplier pyramids, which means that the process has also limitations within the existing production networks. Researchers also call 
attention to the differences between the individual national economies of EastCentral European countries, as well as within the value chains of different carmakers. The embeddedness of transnational firms (development level of supplier system affecting the local value added) is a central question of the papers having comparative character or providing in-depth analyses of the automotive industry in one country (Pavlínek 2002; Klauber et al. 2011). It is usually the automotive industry of Czechia that is considered to be the most developed in the region, where on the basis of the former national car manufacturer (Skoda) a large-volume assembly of cars, a significant parts manufacturing activity, also integrating domestic suppliers, as well as a considerable R\&D function emerged (Pavlínek, Domanski, Guzik 2009). But, even there, we can experience the duality of multinational corporations and the domestically owned small and medium-size enterprises: local enterprises are often pushed back to the lower segments of the supplier pyramids, which offer more limited advantages and competition mostly in terms of prices (Rugraff 2010; Pavlínek, Ženka 2011).

With growing capacities and upgrading of the region's automotive industry, the agglomeration effects are gaining importance in the location choice of the sector, which have led to the emergence of major industrial concentrations in various countries (Grosz 2006; Pavlínek, Janák 2007; Gwosdz, Micek 2010) as well as to a regionally differentiated contribution of the sector to local economy (Ženka, Pavlínek 2013). While embeddedness and agglomeration processes are interpreted as local phenomena, within the boundaries of one national economy, our main idea is the assumption that these tendencies affecting the location choice of the industry have an increasingly cross-border (regional) character. We attempt to measure these tendencies with the data related to the intra-regional trade relations.

\section{Describing intra-regional trade relations}

According to the upgrading of the region described in the literature, the level of automotive exports of the examined countries increased spectacularly between 2001 and 2008. After that, due to the recession, there was a slight regression, but then in 2013 it increased to levels never seen before (Fig. 1). In 2013, East-Central Europe provided for 7-8\% of the world's and 15-16\% of the EU-27's exports in the field of the automotive industry. The export of parts and components, however, which exhibited a similar rate of growth, accounted for nearly $10 \%$ of the world's and more than $20 \%$ of the EU-27's figures. In the course of the decade, the foreign trade balance of all these countries became positive, and the surplus of the region altogether increased further, in which the drop in the local purchase of motor vehicles, as a result of the economic recession after 2008, also played a role. On the basis of their relative export surplus, these countries belonged to the leading European countries of the industry (Fig. 2).

The dominant part of the automotive trade of East-Central European countries - both in terms of exports and imports - is related to the core regions of the European Union. Germany is the most important trading partner: in 2013, it was $30 \%$ of the full automotive exports of the region that went to Germany, 


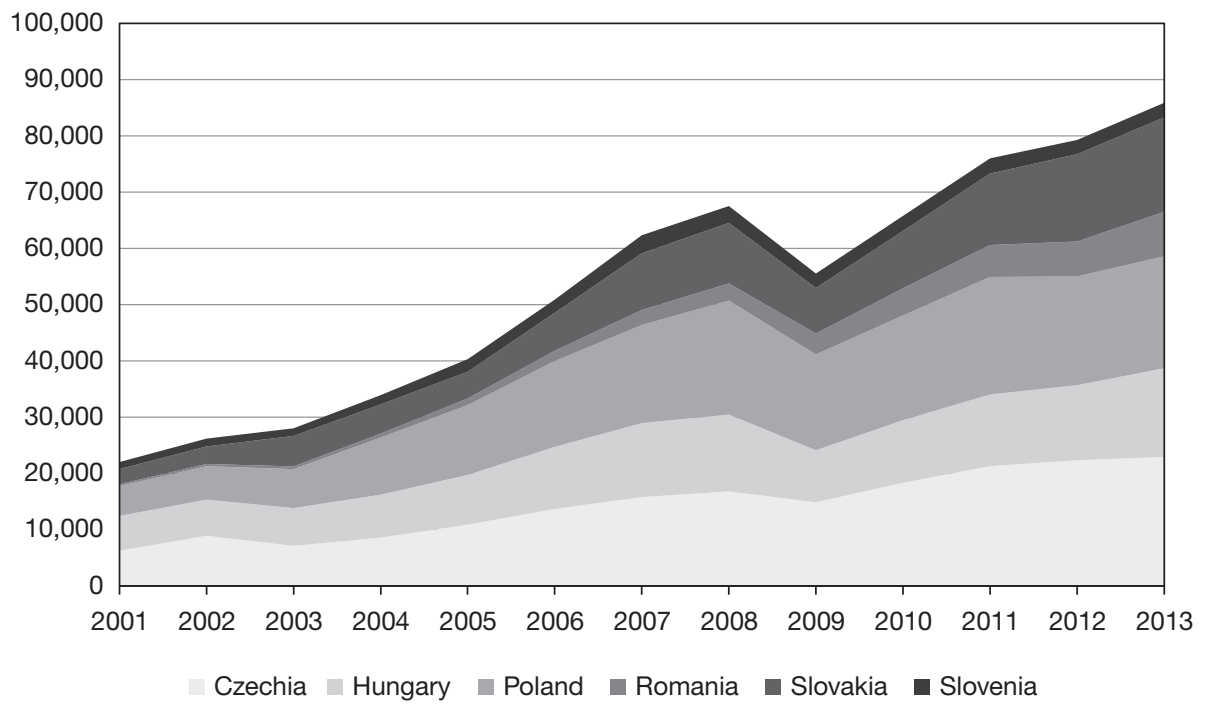

Fig. 1 - The automotive exports of the countries examined (in units of million EUR). Source: based on ITC database.

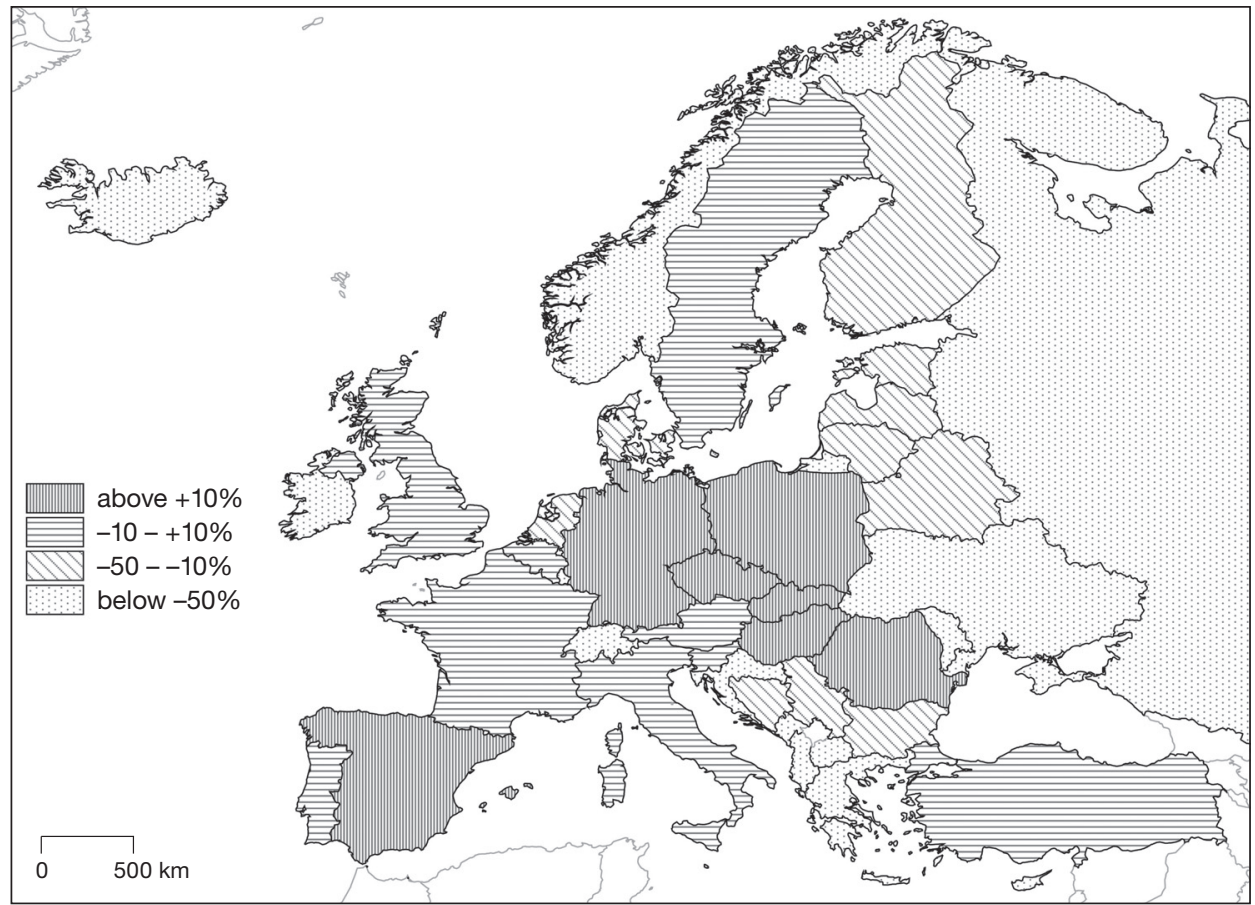

Fig. 2 - The balance of trade of European countries in the automotive industry (shown as a percentage of the total trade of automotive products). Source: based on ITC database. 


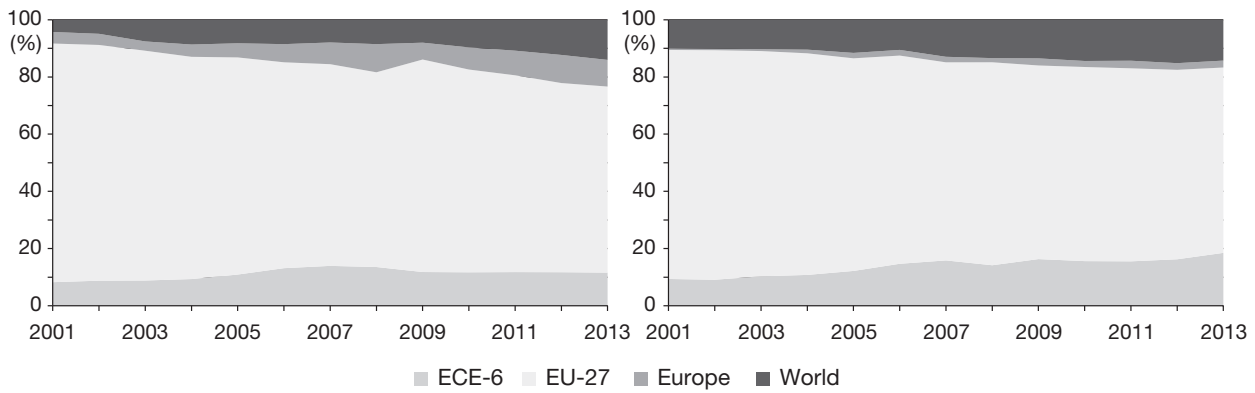

Fig. 3 - The share of the various regions in the automotive export (left) and import (right) of East-Central Europe. ECE-6 - the group of the countries examined, EU-27 - EU member states other than the countries examined; Europe: European countries outside the EU; World: countries outside Europe. Source: based on ITC database.

Table 1 - The distribution of the East-Central Europe's automotive imports by regions (\%)

\begin{tabular}{|lrrrrrrr|}
\hline Automotive products total & 2001 & 2003 & 2005 & 2007 & 2009 & 2011 & 2013 \\
\hline ECE-6 & 9.4 & 10.3 & 12.2 & 15.9 & 16.3 & 15.5 & 18.5 \\
EU-27 & 80.1 & 78.8 & 74.3 & 69.3 & 67.7 & 67.5 & 64.8 \\
- Germany & 45.1 & 42.2 & 41.5 & 36.9 & 36.3 & 37.6 & 35.6 \\
Europe & 0.6 & 0.6 & 1.9 & 1.9 & 2.5 & 2.7 & 2.4 \\
World & 9.9 & 10.3 & 11.6 & 13.0 & 13.5 & 14.3 & 14.3 \\
\hline Automotive components & 2001 & 2003 & 2005 & 2007 & 2009 & 2011 & 2013 \\
\hline ECE-6 & 8.2 & 10.1 & 11.5 & 16.4 & 17.3 & 15.9 & 20.7 \\
EU-27 & 83.4 & 81.6 & 78.5 & 70.3 & 69.3 & 65.9 & 61.7 \\
- Germany & 51.3 & 50.0 & 47.1 & 42.1 & 41.3 & 41.8 & 37.8 \\
Europe & 0.9 & 0.9 & 1.7 & 2.5 & 2.4 & 3.1 & 2.8 \\
World & 7.5 & 7.3 & 8.3 & 10.9 & 11.0 & 15.1 & 14.8 \\
\hline Engines (gasoline/diesel) & 2001 & 2003 & 2005 & 2007 & 2009 & 2011 & 2013 \\
\hline ECE-6 & 15.4 & 23.1 & 29.1 & 39.0 & 28.2 & 27.8 & 31.7 \\
EU-27 & 70.9 & 66.5 & 63.1 & 49.4 & 58.2 & 52.8 & 53.1 \\
- Germany & 41.3 & 40.1 & 40.2 & 21.1 & 20.8 & 27.1 & 32.4 \\
Europe & 0.4 & 0.3 & 0.7 & 0.8 & 0.4 & 2.3 & 2.6 \\
World & 13.3 & 10.1 & 7.2 & 10.7 & 13.1 & 17.1 & 12.6 \\
\hline Engine parts (gasoline/diesel) & 2001 & 2003 & 2005 & 2007 & 2009 & 2011 & 2013 \\
\hline ECE-6 & 2.4 & 4.5 & 7.1 & 6.8 & 11.1 & 9.9 & 10.8 \\
EU-27 & 89.3 & 86.6 & 79.6 & 78.0 & 73.0 & 74.9 & 73.5 \\
- Germany & 75.1 & 70.0 & 65.8 & 62.3 & 53.8 & 53.2 & 54.4 \\
Europe & 0.5 & 0.7 & 2.8 & 2.8 & 1.7 & 1.2 & 0.9 \\
World & 7.9 & 8.2 & 10.6 & 12.4 & 14.2 & 13.9 & 14.7 \\
\hline
\end{tabular}

Source: based on ITC database 
Table 2 - The share of East-Central Europe in the automotive exports of the countries in the region (\%)

\begin{tabular}{|c|c|c|c|c|c|c|c|}
\hline Automotive products total & 2001 & 2003 & 2005 & 2007 & 2009 & 2011 & 2013 \\
\hline Czechia & 14.4 & 17.3 & 16.6 & 17.9 & 14.9 & 13.6 & 14.6 \\
\hline Hungary & 4.5 & 7.8 & 12.6 & 19.2 & 14.2 & 16.1 & 11.5 \\
\hline Poland & 5.5 & 4.1 & 7.2 & 10.3 & 9.7 & 9.1 & 10.7 \\
\hline Romania & 16.0 & 7.7 & 9.5 & 6.1 & 6.5 & 7.9 & 8.4 \\
\hline Slovakia & 8.8 & 5.8 & 8.1 & 9.8 & 11.9 & 11.4 & 10.6 \\
\hline Slovenia & 4.6 & 6.3 & 4.0 & 12.3 & 6.8 & 7.5 & 8.4 \\
\hline ECE-6 & 8.2 & 8.8 & 10.9 & 13.9 & 11.8 & 11.8 & 11.6 \\
\hline Automotive components & 2001 & 2003 & 2005 & 2007 & 2009 & 2011 & 2013 \\
\hline Czechia & 11.8 & 13.0 & 12.9 & 18.9 & 19.0 & 18.5 & 20.6 \\
\hline Hungary & 6.3 & 10.5 & 10.3 & 13.7 & 14.8 & 13.8 & 15.2 \\
\hline Poland & 8.4 & 7.3 & 8.1 & 13.4 & 14.8 & 14.7 & 18.0 \\
\hline Romania & 9.1 & 5.3 & 5.9 & 7.9 & 11.0 & 10.8 & 12.4 \\
\hline Slovakia & 17.5 & 9.6 & 17.9 & 20.7 & 20.8 & 21.8 & 22.5 \\
\hline Slovenia & 0.8 & 2.9 & 8.2 & 15.2 & 18.4 & 15.8 & 15.3 \\
\hline ECE-6 & 10.0 & 10.1 & 10.9 & 15.5 & 16.5 & 16.1 & 18.2 \\
\hline Engines (gasoline/diesel) & 2001 & 2003 & 2005 & 2007 & 2009 & 2011 & 2013 \\
\hline Czechia & 62.8 & 33.7 & 19.5 & 10.2 & 5.9 & 3.8 & 3.1 \\
\hline Hungary & 5.8 & 9.6 & 12.5 & 19.8 & 11.3 & 17.5 & 11.5 \\
\hline Poland & 0.3 & 0.9 & 6.8 & 13.7 & 23.9 & 15.4 & 18.9 \\
\hline Romania & 44.2 & 61.7 & 18.2 & 0.6 & 0.0 & 0.0 & 0.0 \\
\hline Slovakia & 16.2 & 9.0 & 7.0 & 2.3 & 1.8 & 57.7 & 61.2 \\
\hline Slovenia & 1.1 & 1.4 & 0.3 & 0.5 & 0.5 & 1.3 & 0.1 \\
\hline ECE-6 & 5.1 & 7.4 & 10.7 & 16.7 & 15.1 & 18.3 & 16.4 \\
\hline Engine parts (gasoline/diesel) & 2001 & 2003 & 2005 & 2007 & 2009 & 2011 & 2013 \\
\hline Czechia & 7.6 & 7.4 & 20.1 & 10.2 & 9.1 & 8.5 & 11.1 \\
\hline Hungary & 1.0 & 1.2 & 3.7 & 18.8 & 18.0 & 14.8 & 12.3 \\
\hline Poland & 4.6 & 12.5 & 31.6 & 12.3 & 12.1 & 12.4 & 8.8 \\
\hline Romania & 5.6 & 5.5 & 1.5 & 0.4 & 0.7 & 3.0 & 2.5 \\
\hline Slovakia & 11.7 & 6.5 & 26.7 & 30.5 & 37.8 & 29.8 & 27.6 \\
\hline Slovenia & 0.2 & 1.4 & 11.0 & 13.9 & 16.2 & 20.4 & 21.6 \\
\hline ECE-6 & 4.2 & 6.3 & 15.6 & 13.7 & 13.3 & 12.2 & 10.6 \\
\hline
\end{tabular}

Source: based on ITC database

while in the case of intermediate products this proportion was close to $40 \%$. In the longer term, however, a decrease of the significance of the core regions and Germany is expected, which in the field of exports will be concomitant with an increase of the share of markets outside the EU; while in the field of imports, with more emphasis on intra-regional (ECE-6) relations in East-Central Europe (Fig. 3).

Despite the dominance of the European core regions, the increase of the proportion of the regional import of automotive parts, engines and engine parts is 
Table 3 - Some characteristic features of the intra-regional trade of automotive industry in East-Central Europe

\begin{tabular}{|lrrrrrrr|}
\hline & 2001 & 2003 & 2005 & 2007 & 2009 & 2011 & 2013 \\
\hline $\begin{array}{l}\text { Export volume } \\
\text { (in 1,000 euros) }\end{array}$ & 1,813152 & 2,471700 & 4,395069 & 8,685952 & 6,546841 & 8,942063 & 10,054686 \\
$\begin{array}{l}\text { Proportion of } \\
\text { components (\%) }\end{array}$ & 43.2 & 51.4 & 49.8 & 49.8 & 55.1 & 61.2 & 64.6 \\
$\begin{array}{l}\text { Proportion of } \\
\text { top 10 relations } \\
\text { (total, \%) }\end{array}$ & 83.0 & 88.2 & 81.7 & 76.7 & 77.7 & 75.6 & 75.6 \\
$\begin{array}{l}\text { Proportion of } \\
\text { top 10 relations } \\
\text { (components, \%) }\end{array}$ & 91.8 & 92.9 & 88.7 & 88.0 & 83.1 & 82.8 & 81.1 \\
\hline
\end{tabular}

Source: based on ITC database

noteworthy, which occurred in the case of all three of the above product groups at the expense of the core areas of the European Union. From among various intermediate parts, it is the sourcing of engine parts that is least related to the region: in this respect, the weight of Germany (over 50\%) is outstanding, and - by reason of the investments made by Asian companies - the share of trade relations outside Europe is also higher than the average of the region (Table 1).

There are major differences in the East-Central European orientation of the automotive exports in the case of the countries examined (Table 2). Throughout the entire period, the exports of Czechia went to East-Central Europe at above average rates. As a counterpoint to the above, the intra-regional exports of Romania increased spectacularly, yet even today it shows the lowest level of regional orientation in all product groups: the main markets of the motor vehicles and parts are located outside the core areas or even outside the boundaries of the EU (Russia, Turkey, Algeria). Hungary's situation could be initially characterized by a strong dominance of the EU's core areas, but the export of small cars, engines and engine parts has increasingly turned towards Czechia, Poland and Slovakia. The share of the region within the Hungarian exports became the largest by the second part of the decade (Table 2). In recent years, however, pushing the boundaries of the regional production frameworks, an increase in the role of markets other than Europe can be observed in the case of several products.

Between 2001 and 2008, the volume of automotive export among the countries examined increased from 1.8 billion EUR to over 9 billion EUR, and after a major drop in 2009, it jumped to over 10 billion EUR in 2013. In the intraregional trade, parts and components play an increasingly important role, which has spectacularly reinforced its positions even after the decline in the sale of motor vehicles in the region during the period of the economic crisis. The majority of the intra-regional trade is concentrated by only some relations, while the concentration level of parts and components trade is even higher (Table 3).

The largest increase of volume - in terms of the total volume of trade, as well as parts and components - was in the trade relations between countries in Central Europe (Radics 2005; Khademi-Vidra 2014). On the basis of the 

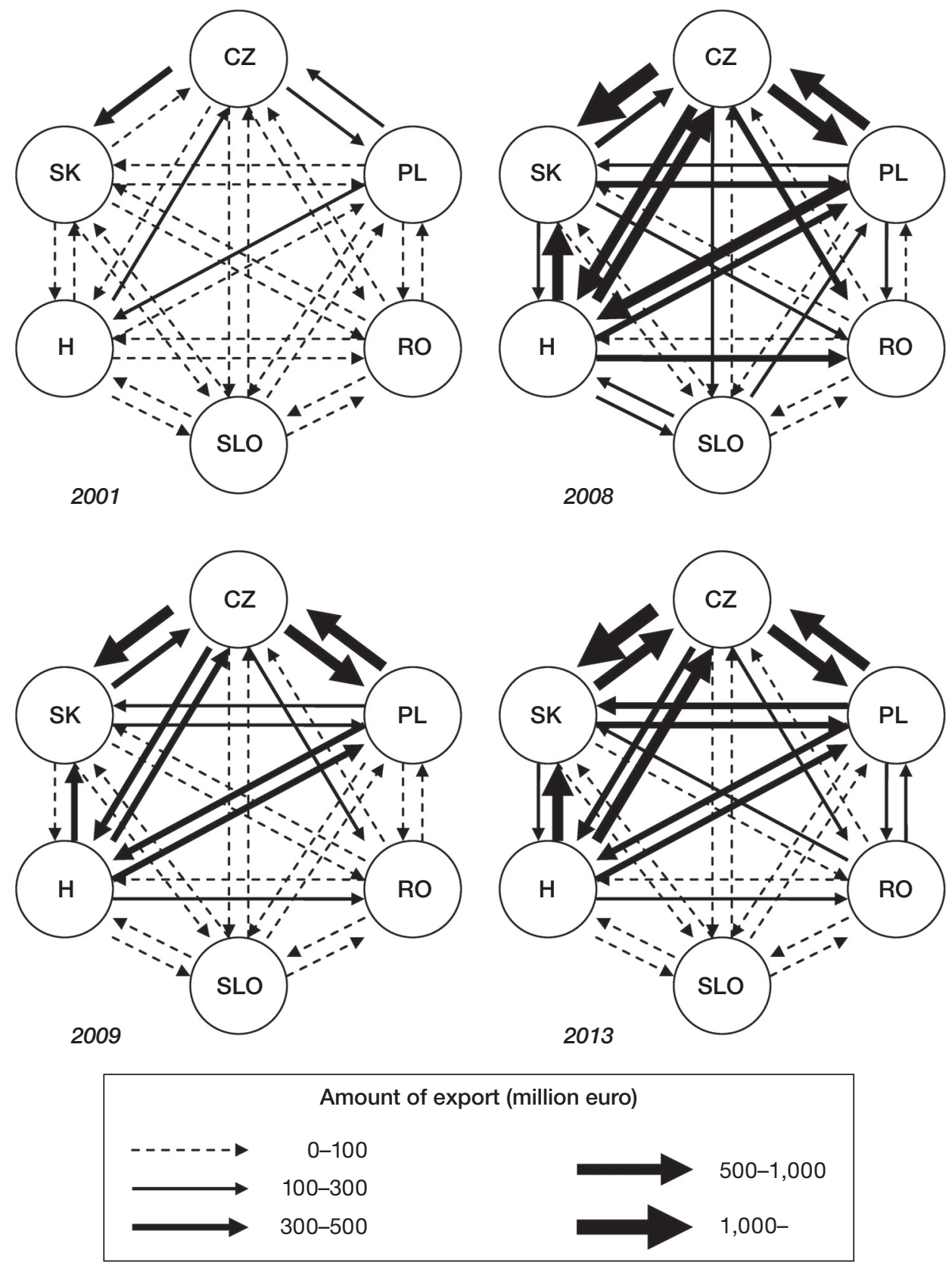

Fig. 4 - The volume of automotive trade among the countries examined 

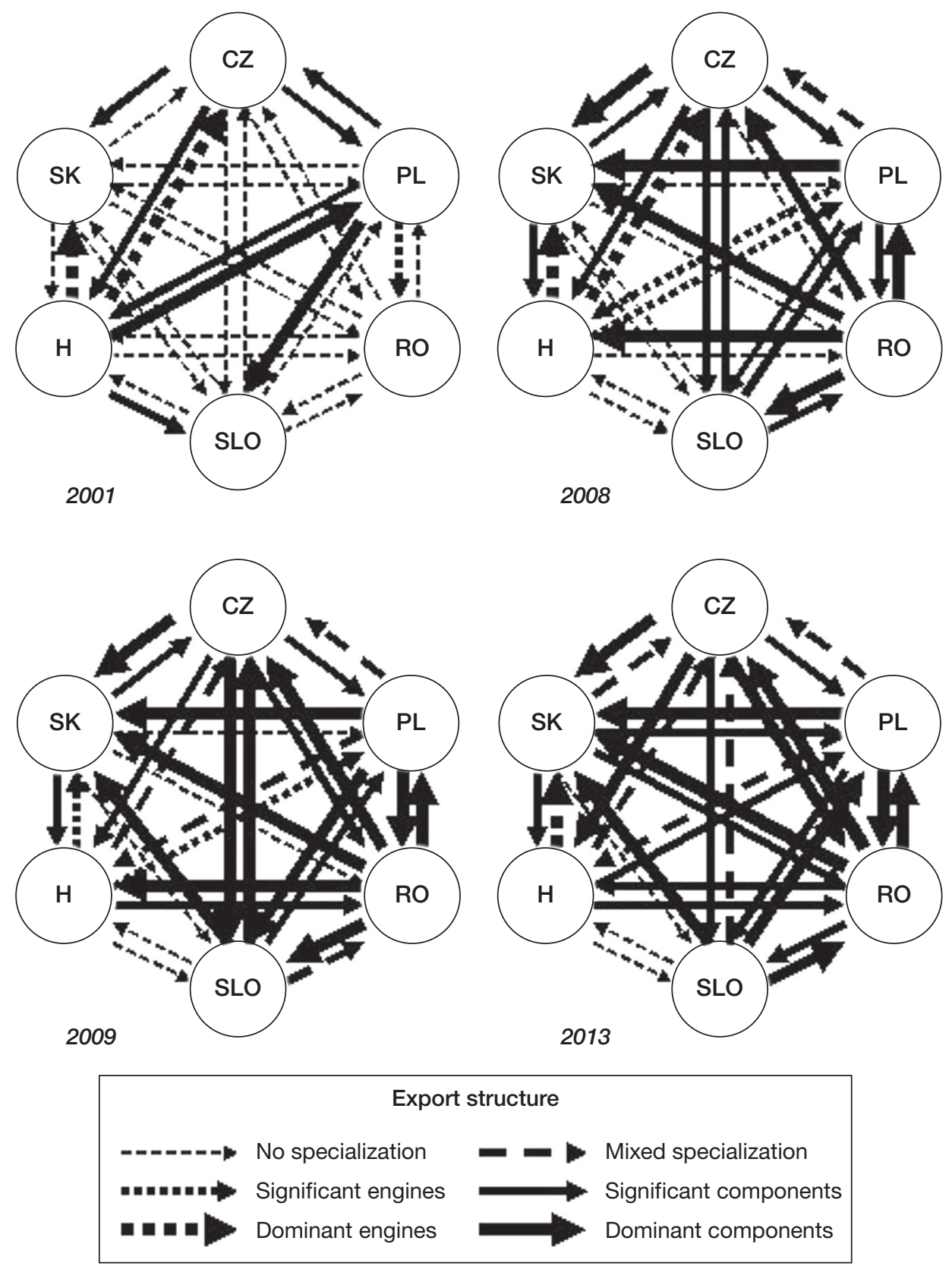

Fig. 5 - The trade of motor vehicle parts and components among the countries examined 
scale of the trade relations, three distinctive groups can be identified in the region. First of all, Czechia has very intensive trade relations with Poland and Slovakia. (In 2013, these relations accounted for $25 \%$ and $20 \%$ of the total volume of intra-regional sales in the automotive industry, respectively.) Secondly, Hungary has a significant volume of trade with the other three Central European countries. Thirdly, there are trade relations of much smaller volume between Romania and Slovenia and the other four countries (Fig. 4). With the growing value associated with the parts and components trade, the number of intra-regional relations in which the trade of various vehicle parts, engines and engine parts played a significant role continuously increased (from 50\% in 2001 to $90 \%$ in 2013): there is a shift in the intra-regional trade toward intermediate products in almost every trade relations within the East-Central European region (Fig. 5).

\section{Explaining intra-regional trade relations}

Because of the organizational structure of the sector described above, as well as the leading role of foreign direct investments in the East-Central European automotive industry, the regional and structural pattern of trade relations can be explained as a consequence of the strategies of transnational car manufacturers and main suppliers leading the value chains of the automotive industry. The statement can be underpinned also by our research in Hungary. According to the data of the MAJOSZ (Association of Hungarian Automotive Component Manufacturers), 54\% of all automotive suppliers are locally owned firms (2012), while the biggest exporters of automotive products are without exception subsidiaries of transnational firms (Table 4). The Hungarian automotive industry undoubtedly presents an extreme case: greenfield investments played an above average role. However, due to the denationalization processes (suppliers from the socialist era predominantly bought up by foreign companies), the tendencies can be generalized also for countries with existing car industries before the change of regime (Pavlínek 2002; Humphrey, Memedovic 2003; Szewczyk, Łobos 2012).

Our analysis reinforces the findings known from the literature, namely that the automotive production of the European periphery is primarily aimed at the leading markets of the European Union (Humphrey, Memedovic 2003; Dicken 2011). Within the EU, Germany is the biggest automotive market, the importance of which is further increased by the fact that a significant part of the car manufacturers making investments in East-Central Europe originated in Germany. According to Schamp, the EU market has a "quasi-integrated" nature arising from differences in consumer preferences, which in the case of car-makers primarily means, even today, the outstanding role of their parent countries as markets of consumption (Schamp 2005). There are also explanations for the export of parts and components to Germany: the German automotive industry, in order to increase its competitiveness, successfully carried out a shift in its geographical orientation by way of choosing cost-efficient plant locations in East-Central Europe (Jürgens, Krzywdzinski 2009, 2011). In the background of the same export destination, we can see also the differences 
Table 4 - Leading exporters of automotive products in Hungary

\begin{tabular}{|lr|}
\hline Enterprise & Export revenues (2013, million EUR) \\
\hline Audi Hungaria Motor Ltd. & 5,772 \\
Mercedes-Benz Manufacturing Hungary Ltd. & 2,067 \\
Magyar Suzuki Co. & 1,473 \\
Robert Bosch Elektronika Ltd. & 1,179 \\
Continental Automotive Hungary Ltd. & 688 \\
\hline Lear Corporation Hungary Ltd. & 622 \\
Robert Bosch Energy and Body Systems Ltd. & 611 \\
Michelin Hungária Abroncsgyártó Ltd. & 568 \\
LuK Savaria Kuplunggyártó Ltd. & 518 \\
Hankook Tire Magyarország Ltd. & 487 \\
\hline Harman Becker Ltd. & 469 \\
Denso Gyártó Magyarország Ltd. & 468 \\
Delphi Hungary Ltd. & 456 \\
BorgWarner Turbo Systems Ltd. & 326 \\
SMR Automotive Mirror Technology Lp. & 298 \\
\hline Johnson Controls Mór Lp. & 295 \\
Ibiden Hungary Ltd. & 254 \\
\hline
\end{tabular}

$1 \mathrm{EUR}=300 \mathrm{HUF}$

Source: HVG, 30/2014

between the motivations of European and Asian operators: in the case of the former, the aim is to increase the efficiency of the production for the domestic (EU) market, while in the case of the latter, the main purpose is gaining access to the EU market, at the same time having the advantage of cost-efficient production location (Pavlínek 2002; Radosevic, Rozeik 2005). According to our experiences in Hungary, the tendency can also be extended to component manufacturers from Asia: there are more Japanese suppliers producing from Hungary for more buyers in Europe (Spain, UK).

The emerging role of intra-regional import combined with the growing significance of parts and components can be explained by the appearance of an increasing number of transnational suppliers choosing this region because of the possibility of cost-efficient production. On the other hand, in the background of these tendencies we find the efforts of the regionally established car manufacturers and their leading suppliers to reduce logistics costs and to increase the flexibility of production by having partners locally. Our experiences in Hungary show that these strategies are apparent not only by the existence of purchasing bureaus of VW in Budapest and Audi in Györ, but - for example also by the moderate growth of local content in the engine production described earlier as an activity of pure assembly character. The $10 \%$ rate of local suppliers in the case of VW-Audi $10 \%$ and $10-20 \%$ rate in the case of GM-Opel (Sass, Szanyi 2004; Kemenczei, Nikodémus 2006) increased to 20-25\% in the period examined. As the examples of car-makers in Hungary or the Slovakian PSA plant show, the suppliers are sought not only within one national economy in 
the region and not only for one plant, which increases the volume of automotive components trade. In the case of the Asian car manufacturers the local content requirements $(60 \%)$ also play an important role in the growth of intra-regional inputs as the case of Suzuki already in the 1990s showed.

We can also explain the increasing regionalization of the sourcing activities with reference to economies of scale (Humphrey, Memedovic 2003; Schamp 2005) preferring strategies aiming the geographical concentration of production activities and the supply of buyers from one or few bigger plants. With the largest engine plant of the world, Hungary was 2013 the world's second largest gasoline engine exporter, also having the fifth place in the field of diesel engines. The engine and engine parts trade based on the export of some producers in Hungary, Poland and Slovakia accounted for 55\% of the Hungarian-Slovakian relation, $40 \%$ of the Slovakian-Czech exports, and 30 to $40 \%$ each of the Polish-Czech and the Hungarian-Czech relation. Another example for the spatial concentration of the activities offers tire production. After realizing the actually planned capacity extensions and greenfield investments (2017), Hungary will have a tire production accounting for more than 12\% of all European sales in 2012 (Hungarian Tire Association). With the growing production capacities there is also change in the structure of the local content: Suzuki initially having local suppliers in order to meet the European requirements was followed by more Japanese firms after the plant reached a critical size (Rugraff, Sass 2012). The concept of production next to the buyers is gaining importance in the choice of location. The results of our research in Hungarian industrial parks show that this factor played an above average role in Northern Transdanubia where a significant part of Hungarian automotive industry is concentrated (Molnár 2013).

The predominance of trade relations between the four countries of Central Europe is to explain the uneven presence of foreign direct investments. Playing a decisive role in the intertwining of Czechia, Hungary, Poland and Slovakia are the same car-makers and their leading suppliers present in several countries: the Volkswagen group has interests in all four countries, but there are also other car-makers (and their main suppliers) pursuing activities in more than one Central European country, such as GM (in Poland and Hungary), PSA (in Czechia and Slovakia), Toyota (in Czechia and Poland), as well as HyundaiKia (in Czechia and Slovakia). The majority of the trade relations that have achieved outstanding increases are related to Slovakia, which - also taking into consideration the fact that it is the only country in the group which has a significant intra-regional trade deficit - is primarily due to the high demand of its assembly plants (VW, PSA, Kia) for parts. The intensification of the parts and components trade proves the dynamic force that the neighbouring countries have on each other's economies (Barta 2012). The Hungarian-Slovakian relation is Hungary's largest and most dynamic export direction within the region, where the extension of trade is also greatly facilitated by the proximity of the car manufacturing plants in Western Slovakia to the industrial companies in the Northern Transdanubian part of Hungary. According to this spatial concentration, the automotive industry has significant role in the economic restructuring and development of these areas causing also new regional disparities (Pénzes 2013). 


\section{Conclusions}

The increasing trade of automotive products in East-Central Europe is characterized (besides the dominant linkages to the core area of the EU) by the growing importance of intra-regional import, the prevalence of the relations between the four Central European countries, as well as the emerging role of the parts and components trade. The special role of Germany as a source of imports of automotive parts and components, and also as the country from which a significant part of the automotive firms settled in the region are controlled, reinforces the conclusion that East-Central Europe can be considered as the eastern part of an emerging Central European automotive district with Germany at its centre.

The increase of the significance of the critical mass and the intra-regional relationships of the industry further intensifies the mutual dependence of these countries in the location choice, which justifies moving beyond the traditional point of view emphasizing only the competition within the region. A key element of the increasing local value added, considered to be of significance from the point of view of the long-term establishment of the automotive industry in East-Central Europe, is the network of suppliers. The regionalization of the sourcing activities of the stakeholders increasingly calls for a study of the embeddedness of automotive value chains with an approach crossing the boundaries of national economies.

\section{References:}

AKBAR, Y.H., FERENCIKOVA, S. (2007): Industrial clustering and global value chains in Central and Eastern Europe: role of multinational enterprises in industrial upgrading. Prague Economic Papers, 12, No. 3, pp. 237-251.

BARTA, G.Y. (2012): Central and Eastern European Automotive Industry in European Context. In: Rechnitzer, J., Smahó, M. (eds.): Vehicle Industry and Competitiveness of Regions in Central and Eastern Europe. Universitas-Győr Nonprofit Kft., Győr, pp. 33-70.

DICKEN, P. (2011): Global Shift. Mapping the Changing Contours of the World Economy. Sage, Los Angeles, $607 \mathrm{pp}$.

FUCHS, M., WINTER, J. (2008): Competencies in subsidiaries of multinational companies. The case of the automotive supply industry in Poland. Zeitschrift für Wirtschaftsgeographie, 52, No. 4, pp. 209-220.

GEREFFI, G., HUMPHREY, J., STURGEON, T. (2005): The governance of global value chains. Review of International Political Economy, 12, No. 1, pp. 78-104.

GROSZ, A. (2006): Clusterisation Processes in the Hungarian Automotive Industry. Hungarian Academy of Sciences, Centre for Regional Studies, Pécs.

GWOSDZ, K., MICEK, G. (2010): Spatial agglomerations in the Polish automotive industry. Przeglad Geograficzny, 82, No. 2, pp. 159-190.

HAGIU, A., PLATIS, M. (2012): The Evolution of the Romanian Car Industry and Its Position on European Market. Studia Universitatis Babes - Bolyai Negotia, 57, No. 2, pp. 65-91.

HAVAS, A. (2007): The Interplay between Innovation and Production Systems at Various Levels: The case of the Hungarian automotive industry. Paper presented at The $5^{\text {th }}$ International GLOBELICS Conference "Regional and National Innovation Systems for Development, Competitiveness and Welfare” Saratov, Russia, September 19-23, 2007.

HUMPHREY, J., MEMEDOVIC, O. (2003): The global automotive industry value chain: what prospects for upgrading by developing countries. UNIDO, Vienna, $62 \mathrm{pp}$. 
JÜRGENS, U., KRZYWDZINSKI, M. (2009): Changing East-West division of labour in the European automotive industry. European Urban and Regional Studies, 16, No. 1, pp. 27-42.

JÜRGENS, U., KRZYWDZINSKI, M. (2011): Die neue Ost-West-Arbeitsteilung. Campus Verlag, Frankfurt/New York, $258 \mathrm{pp}$.

KEMENCZEI, N., NIKODÉMUS, A. (2006): Autóipari trendek a nagyvilágban és hazánkban. Külgazdaság, 50, No. 3, pp. 57-66.

KHADEMI-VIDRA, A. (2014): Consumer habits form the perspective of the global economic crisis in East-Central Europe. Central European Regional Policy and Human Geography, 4, No. 1, pp. 37-47.

KISS, É. (2007): The impacts of relocation on the spatial pattern to Hungarian industry. Geographia Polonica, 80, No. 1, pp. 43-61.

KLAUBER, M., GYUKICS, R., PALOCZ, É., PÁCZI, E., VAKHAL, P. (2011): A magyar kis és középvállalatok beszállítói szerepének erősítéséről szóló stratégia kidolgozása a gép- és gépjárműipari ágazatban: a jelenlegi helyzet tanulságai és a lehetőségek kihasználásának eszközei. Kopint Alapítvány, Budapest, 53 pp.

MOLNÁR, E. (2009): A világ autóiparának változó földrajza. Földrajzi Közlemények, 133, No. $1-2$, pp. 105-120.

MOLNÁR, E. (2013): Az autóipar, mint húzóágazat az ipari parkokban: telephelyválasztás, közlekedési adottságok. In: Kiss, É. (ed.): A hazai ipari parkok különböző dimenzióban. Dialóg Campus Kiadó, Budapest, Pécs, pp. 210-235.

PAVLÍNEK, P. (2002): Transformation of the Central and East European passenger car industry: selective peripheral integration through foreign direct investment. Environment and Planning A, 34, No. 9, pp. 1685-1709.

PAVLÍNEK, P., DOMANSKI, B., GUZIK, R. (2009): Industrial upgrading through foreign direct investment in Central European automotive manufacturing. European Urban and Regional Studies, 16, No. 1, pp. 43-63.

PAVLINEK, P., JANÁK, L. (2007): Regional restructuring of the Skoda Auto supplier network in the Czech Republic. European Urban and Regional Studies, 14, No. 2, pp. 133-155.

PAVLÍNEK, P., ŽENKA, J. (2011): Upgrading in the automotive industry: firm-level evidence from Central Europe. Journal of Economic Geography, 11, No. 3, pp. 559-586.

PÉNZES, J. (2013): The dimensions of peripheral areas and their restructuring in Central Europe. Hungarian Geographical Bulletin, 62, No. 4, pp. 373-386.

RADICS, Z. (2005): The effect of free-trade organizations on the economic formation of regions and the regional development in Central Europe. In: Problemi Regionalnog razvoja Hrvatske i susjednih zemalja, Hrvatsko Geografsko Drustvo, Zagreb, pp. 123-134.

RADOSEVIC, S., ROZEIK, A. (2005): Foreign direct investment and restructuring in the automotive industry in Central and East Europe. University College London, Centre for the Study of Economic and Social Change in Europe, $41 \mathrm{pp}$.

RUGRAFF, E. (2010): Foreign direct investment (FDI) and supplier-oriented upgrading in the Czech motor vehicle industry. Regional Studies, 44, No. 5, pp. 627-638.

RUGRAFF, E., SASS, M. (2012): Válság és relokációs fenyegetés a feltörekvő országokban: a magyar autóipar esete. Külgazdaság, 56, No. 9-10, pp. 4-29.

SASS, M., SZANYI, M. (2004): Is Crowding In a Real Option?: The Development of Supplier Linkages of local firms to multinational corporations. In: Zeidritsch, R. (ed.): Internationales management in den Märkten Mittel- und Osteuropas. Rainer Hampp Verlag, München, pp. 367-390.

SCHAMP, E.W. (2005): Die Autoindustrie auf dem Weg nach Europa. Zur Integration nationaler Standortsysteme der Autoproduktion. Geographische Rundschau, 57, No. 12, pp. 12-19.

STURGEON, T., VAN BIESEBROECK, J., GEREFFI, G. (2008): Value chains, networks and clusters: reframing the global automotive industry. Journal of Economic Geography, 8, No. 3, pp. 297-321.

SZALAVETZ, A. (2011): Die ungarische Automobilindustrie - eine vergleichende MOEPerspektive mit besonderem Schwerpunkt auf dem strukturellen Wandel. In: Welfens, P.J.J. (eds.): Cluster- und Innovationsdynamik in Europa. Neue Perspektiven der Automobil- und IKT-Wirtschaft. Lucius \& Lucius, Stuttgart, pp. 480-518. 
SZEWCZYK, M., ŁOBOS, K. (2012): The 100 largest companies in the Czech Republic and Poland in the year 2010: a comparative study of economic performance. Ekonomická revue - Central European Review of Economic Issues, 15, pp. 81-93.

VAN BIESEBROECK, J., STURGEON, T.J. (2010): Effects of the 2008-09 Crisis on the Automotive Industry in Developing Countries: A Global Value Chain Perspective. In: Cattaneo, O., Gereffi, G., Staritz, C. (eds.): Global Value Chains in a Postcrisis World. World Bank Publication, Washington, pp. 209-244.

WINTER, J. (2006): Kompetenzerwerb in der Automobilindustrie: Das Beispiel Volkswagen Poznan (Polen). Geographische Rundschau, 58, No. 4, pp. 46-52.

WÓJTOWICZ, M., RACHWAL, T. (2014): Globalization and New Centres of Automotive Manufacturing - the Case of Brazil, Mexico and Central Europe. Studies of the Industrial Geography Commission of the Polish Geographical Society, 25, pp. 81-107.

ŽENKA, J., PAVLÍNEK, P. (2013): The Czech automotive industry in global production networks: regional dimensions of upgrading between 1998 and 2008. Geografie, 118, No. 2, pp. 116-137.

\section{Shrnutí}

\section{VNITŘNÍ TRH S AUTOMOBILOVÝM PRŮMYSLEM VE STŘEDNÍ EVROPĚ}

Článek se zabývá vnitřním trhem s automobilovým průmyslem ve střední Evropě, kde se stal prioritní oblastí pro přímé zahraniční investice a kde dochází ke vzniku výrobního centra vzrůstajícího významu. Naším předpokladem byla významná role přeshraničních aglomeračních tendencí (reflektovaná vnitroregionálními obchodními vazbami) a regionálního upgradingu. Po provedení rešerše relevantní literatury se článek pouští do analýzy a vysvětlení současných změn ve významu a struktuře regionálních vztahů. Empirický výzkum se zaměřuje na první desetiletí jednadvacátého století, kdy lze v zemích středovýchodní Evropy (Česko, Madarsko, Polsko, Rumunsko, Slovensko, Slovinsko) vypozorovat výraznou přítomnost automobilového průmyslu. Studie vychází z databáze Světového obchodního centra, zejména $\mathrm{z}$ dat o importu a exportu motorových vozidel a jejich částí, či vznětových motorů a jejich součástek. Analýza je potom založená kromě studia relevantní literatury také na informacích mezinárodních organizací v daném sektoru (ACEA, OICA), tiskových zprávách či primárním výzkumu mad’arských sektorových organizací (MAGE - Asociace mad’arských automobilových výrobců, MAJOSZ - Asociace madarských výrobců automobilových součástí) a industriálních parků s automobilovými firmami. Pro narůstající obchod s automobilovými výrobky ve středovýchodní Evropě jsou - kromě převažující vazby na jádrové oblasti Evropské unie - charakteristické zejména rostoucí význam vnitroregionálního dovozu, převládající vazby mezi čtyřmi středoevropskými zeměmi a stále významnější role obchodu se součástmi a komponenty. Vzhledem k jejich strategické pozici, výrobci automobilů stále drží kontrolu nad hodnotovými řetězci, a spolu s předními dodavateli patří v celém procesu k dominantním hráčům. Speciální role Německa jako zdroje dovozů automobilových součástí a lokace odkud je kontrolována většina automobilových firem, které v regionu působí, posiluje vnímání středovýchodní Evropy jako východní části vznikajícího středoevropského automobilového distriktu s centrem v Německem.

Růst významu kritického množství a vnitroregionálních vazeb v lokalizačním rozhodování dále prohlubuje vzájemnou závislost těchto zemí, což nabourává tradiční pohledy preferující význam a vlivy vzájemné soutěže. Klíčovou složkou ve vytváření přidané hodnoty, která je považovaná za nezbytnou pro dlouhodobé fungování automobilového průmyslu ve středovýchodní Evropě, je pozadí dodavatelů. Regionalizace zdrojových aktivit klíčových hráčů vyžaduje pečlivý výzkum zakořenění automobilového průmyslu pomocí metod, které dokáží překročit hranice národních ekonomik. 
Obr. 1 -Automobilové vývozy zkoumaných zemí (v mil. EUR). Zdroj: databáze ITC.

Obr. 2 -Bilance obchodu evropských zemí v automobilovém průmyslu (vyjádřena jako procento celkového objemu obchodu s automobilovými produkty). Zdroj: databáze ITC.

Obr. 3 -Podíl jednotlivých regionů na automobilových exportech (vlevo) a importech (vpravo) ze zemí středovýchodní Evropy. Zdroj: databáze ITC. ECE-6: skupina zkoumaných zemí, EU-27: členské země EU mimo zkoumané státy, Evropa: evropské země mimo Evropskou unii, svět: světové země mimo Evropu.

Obr. 4 -Objem obchodu v automobilovém průmyslu mezi zkoumanými zeměmi.

Obr. 5 -Obchod se součástmi a komponenty motorových vozidel mezi zkoumanými zeměmi.

Authors' affiliation: University of Debrecen, Department of Social Geography and Regional Development Planning, 4032 Debrecen, Hungary; e-mail: molnar.erno@science.unideb.hu, kozma.gabor@science.unideb.hu,penzes.janos@science.unideb.hu.

Initial submission, 9 January 2014; final acceptance 1 July 2015.

\section{Please cite this article as:}

MOLNÁR, E., KOZMA, G., PÉNZES, J. (2015): The intra-regional trade relations in the automotive industry of East-Central Europe. Geografie, 120, No. 3, pp. 297-313. 